\title{
Soil Carbon Sequestration Potential of Climate-Smart Villages in East African Countries
}

\author{
Gebermedihin Ambaw ${ }^{1 *} \mathbb{C}$, John W. Recha ${ }^{1, *(\mathbb{D}}$, Abebe Nigussie ${ }^{2 *}$, Dawit Solomon ${ }^{1 *}$ (i) \\ and Maren Radeny ${ }^{1}(\mathbb{D})$ \\ 1 CGIAR Research Program on Climate Change, Agriculture and Food Security (CCAFS) East Africa, \\ International Livestock Research Institute (ILRI), PO Box 30709-00100 Nairobi, Kenya; \\ g.ambaw@cgiar.org (G.A.); d.solomon@cgiar.org (D.S.); m.radeny@cgiar.org (M.R.) \\ 2 Department of Natural Resources Management, Jimma University, PO Box 307 Jimma, Ethiopia; \\ abebe.nigusie@ju.edu.et \\ * Correspondence: j.recha@cgiar.org
}

Received: 1 September 2020; Accepted: 6 October 2020; Published: 30 October 2020

\begin{abstract}
Climate-Smart Villages (CSVs) were established by the CGIAR Research Program on Climate Change, Agriculture and Food Security (CCAFS) in the East African countries of Kenya, Tanzania and Uganda to test and promote a portfolio of climate-smart agriculture (CSA) practices that have climate change mitigation potential. This study evaluated the soil carbon sequestration potential of these CSVs compared to the control land use that did not have CSA practices. At the one-meter depth, soil carbon stocks increased by $20-70 \%, 70-86 \%$, and $51-110 \%$ in Kenya, Tanzania and Uganda CSVs, respectively, compared to control. Consequently, CSVs contributed to the reduction of emissions by $87-420 \mathrm{Mg} \mathrm{CO}_{2}$ eq ha ${ }^{-1}$. In the topsoil $(0-15 \mathrm{~cm}), \mathrm{CSV}_{\mathrm{s}}$ sequestered almost twice more soil carbon than the control and subsequently emissions were reduced by $42-158 \mathrm{Mg} \mathrm{CO}_{2}$ eq ha ${ }^{-1}$ under CSVs. The annual increase in carbon sequestration under CSVs ranged between 1.6 and $6.2 \mathrm{MgC} \mathrm{ha}^{-1} \mathrm{yr}^{-1}$ and substantially varied between the CSA land use types. The forests sequestered the highest soil carbon (5-6 Mg C ha-1 $\mathrm{yr}^{-1}$ ), followed by grasslands and croplands. The forest topsoil also had lower bulk density compared to the control. The findings suggest that CSA practices implemented through the CSVs approach contribute to climate change mitigation through soil carbon sequestration.
\end{abstract}

Keywords: Climate-Smart Villages; climate-smart agriculture; carbon sequestration; cropland; grassland; agroforestry; forest

\section{Introduction}

Climate change has contributed to reduced agricultural productivity and threatens food security across the world [1]. Climate models have predicted more frequent and prolonged extreme weather events such as droughts and floods. These models consider precipitation data available, and accurate attribution of the causes of drought requires accounting for natural variability, especially El Niño/Southern Oscillation effects, owing to the predilection for wetter land during La Niña events [2]. Climate change has likely hampered food production in East African countries because the agricultural systems are mainly rainfed and characterized by low inputs such as fertilizers, crop protection chemicals (herbicides, insecticides, and fungicides) and improved seeds [3,4]. In addition to climate-related production constraints, soil nutrient depletion is a challenge to food security in the region [5]. Despite its act as a source of GHG emission [6,7], soils play a crucial role in climate change mitigation through carbon sequestration [8,9]. Soils sequester about two-thirds of the terrestrial carbon and contain two to three times more carbon than the atmosphere $[9,10]$. Thus, progressive climate-smart soil management interventions are needed to enhance agricultural production and ensure food security 
in the changing climate. More specifically, soil fertility management that can enhance climate change mitigation through soil carbon sequestration is required.

Soils govern the global carbon cycle [11] because a small change in soil carbon pool has a significant impact on climate change. Soil carbon is however under considerable threat in the sub-Sharan African countries due to land use change [8]; environmental factors (i.e., moisture and temperature) and land management practices [12-14]. Most landscapes in Eastern Africa have gone through a transition from natural rainforest to agricultural fields and/or pasture lands [15]. In Tanzania, for instance, 3.9 million ha of forest was lost between 2010-2017, and the gross annual deforestation rate reached approximately $600,000 \mathrm{ha} \mathrm{yr}^{-1}$ [16]. About $20-50 \%$ of soil carbon is therefore lost in the sub-Saharan African countries due to conversation of natural forests to cropland [17]. Prolonged croplands cultivation also accelerates soil organic matter decomposition and results 20-67\% soil carbon loss [18]. This has necessitated the development of climate-smart interventions in the region to restore degraded landscapes and mitigate climate change through soil carbon sequestration [14].

Recently, several climate-smart agriculture (CSA) practices have been promoted as a systematic approach to ensure soil carbon sequestration and sustainable food production [19,20]. Many studies have been undertaken to evaluate carbon sequestration potential of different CSA practices, such as soil conservation [21]; crop rotation [22]; area enclosures [23]; conservation agriculture [24]; and rotational grazing [25]. Owing to variation between these studies, it is difficult to reach a proven universal conclusion on the effect of CSA practices on soil carbon sequestration. The CGIAR Research Program on Climate Change, Agriculture and Food Security (CCAFS) evaluates and promotes a portfolio of CSA technologies through the Climate-Smart Villages (CSVs) research for development approach [26]. CSVs are clusters of villages which are located across a wide range of agroecological zones with different farmer typologies, climate risks and vulnerabilities [27]. In East Africa, CCAFS started piloting CSVs approach in 2012 with six clusters of villages: Lushoto (Tanzania), Wote and Nyando (Kenya), Hoima and Rakai (Uganda), and Borana (Ethiopia) [3]. However, it is unknown whether these CSVs have higher climate mitigation potential compared to business-as-usual practices. The objective of this study was to quantify the impact of improved land use system using CSA practices on soil carbon sequestration potential of degraded landscapes across CSVs in East African countries. Such studies are crucial to evaluate the contribution of CSVs in climate change mitigation and improving the livelihoods of local communities as per the United Nations Framework Convention on Climate Change (UNFCCC).

\section{Methods}

\subsection{The Study Sites}

The study was done in CSVs across three East African countries, namely Lushoto CSVs in Northeastern Tanzania ( $4^{\circ} 47^{\prime} 24^{\prime \prime} \mathrm{S}$ and $38^{\circ} 24^{\prime} 36^{\prime \prime}$ E, 900-2300 metres above sea level (m.a.s.l), Nyando CSVs in Western Kenya ( $\left(0^{\circ} 16^{\prime} 12^{\prime \prime} \mathrm{S}\right.$ and $35^{\circ} 4^{\prime} 12^{\prime \prime}$ E, 1100-2500 m.a.s.l), and Hoima CSVs in Western Uganda (1 $31^{\prime} 48^{\prime \prime} S$ and $31^{\circ} 32^{\prime} 24^{\prime \prime}$ E, 620-1600 m.a.s.l) (Figure 1). The common vegetation types in the geographical regions are cultivated crops (staple cereal maize and sorghum in mixtures with legumes such as beans and cowpeas), forest, grassland, and agroforestry with fruit crops. In Nyando, the mean annual precipitation is $1200 \mathrm{~mm}$, and annual temperature between 15.6 and $31^{\circ} \mathrm{C}$. In Lushoto, the mean annual rainfall and temperature are between 900 and $1300 \mathrm{~mm}$ and 13.8 and $25.2{ }^{\circ} \mathrm{C}$, respectively. In Hoima, the average annual rainfall is about $1400 \mathrm{~mm}$ with a mean annual temperature between 17.7 and $31.2^{\circ} \mathrm{C}$. 


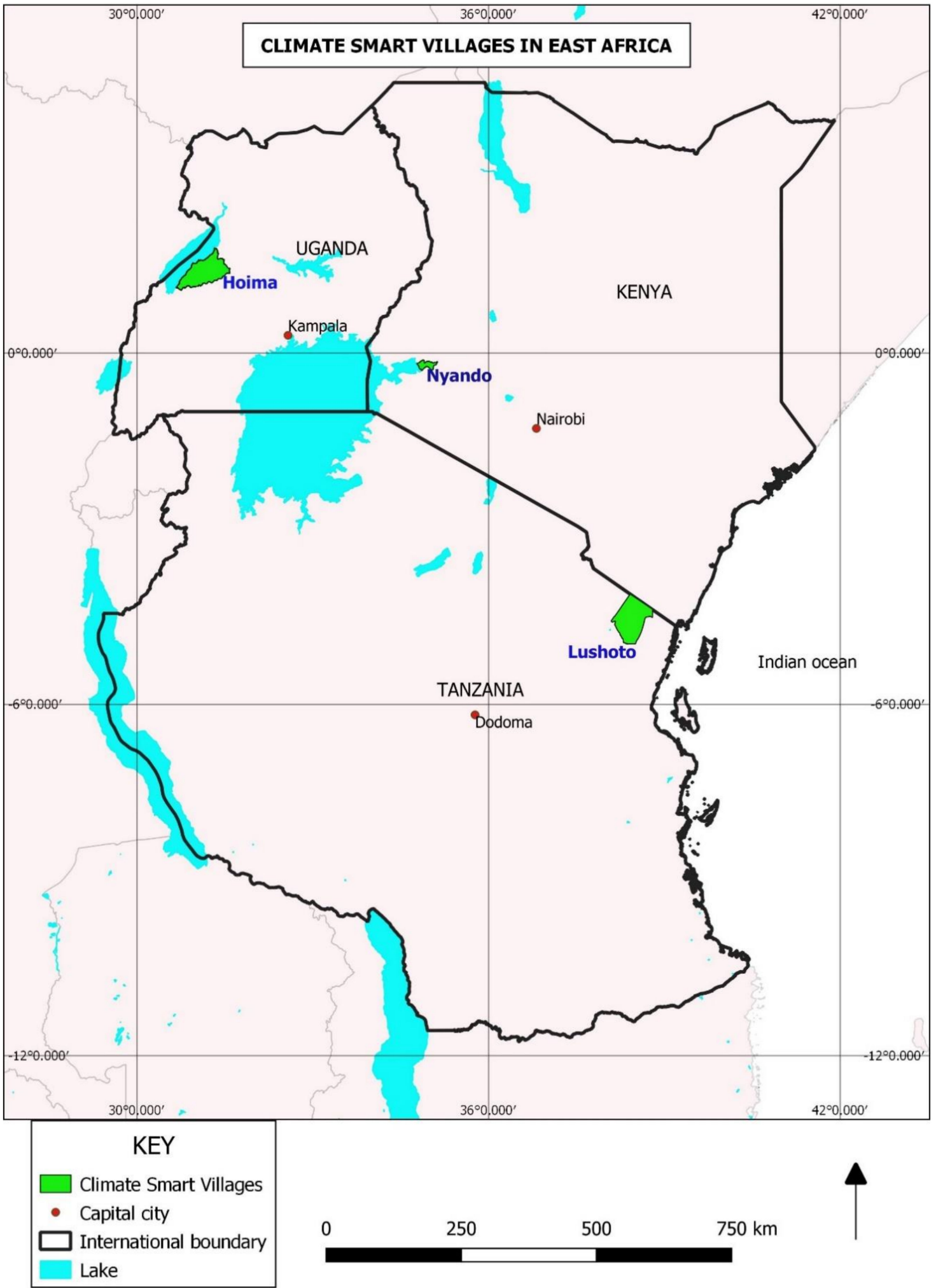

Figure 1. The Hoima, Nyando, and Lushoto Climate-Smart Villages study sites.

Located in Northeastern Tanzania, the Lushoto district forms part of the Eastern Arc Mountains of East Africa. Despite its small area, it is considered a global hotspot for biodiversity due to its numerous micro eco-zones [15]. Maize and beans, both cash and food crops and often intercropped, are the crops of choice for smallholders. Other crops include coffee, cassava, fruits and vegetables-cabbage, 
carrots, sweet pepper, tomato, and soybean. The Lushoto CSVs soil types vary along the topographic gradient, progressing from limited and shallow soils (Regosols and Lithic Leptosols) on the peaks, to more developed soils (Cutanic Acrisols and Ferralic Cambisols) and then to alluvial and wet soils in the valleys (Mollic Gleyic Fluvisols and Fluvic Gleysols) [28]. Many cultivated soils are degraded, with low levels of soil organic carbon indicating limited nutrient retention capacity [15] and observed deficiencies in phosphorus and nitrogen [29]. Nyando CSVs in Western Kenya have a mixed rainfed crop-livestock farming system that is largely subsistence. Farmers mainly grow maize, sorghum, beans, cassava and sweet potatoes. They also keep cattle, small ruminants (sheep and goats) as well as indigenous chicken. The soils in Nyando have varying properties based on elevation. The soils in areas above 1500 m.a.s.l are mostly Luvic Phaeozems. They are deep, porous, clayey soils, which present a high erosion hazard. The soils in the lowlands below 1500 m.a.s.l are a complex mix of Planosols, Vertisols, Cambisols, Fluvisols and Luvisols [30,31]. Generally, soils such as Planosols and Vertisols present problems of poor drainage while Luvisols and Cambisols have high erosion risk especially if cultivated on steep slopes [32]. Hoima CSVs in the Albertine Rift basin of Western Uganda has diverse farming systems that include highland agroforestry, mid-hill coffee/tea, small-scale mixed farming/commercial to dryland small-scale agriculture/agropastoralism farming along Lake Albert. The main crops grown include maize, sorghum, millet, cassava, beans, and sweet potatoes. In the livestock production practices, there is less of cattle but more chicken and pig farming. The soils in Hoima CSVs are mostly Ferralsols (Oxisols in Soil Taxonomy) that are deeply weathered and red. There are some Fluvisols on level topography towards the nearby Lake Albert [33].

\subsection{Soil Sampling and Preparation}

In Hoima, Nyando and Lushoto CSVs, each land use type had six soil profiles that were dug in random locations within the field in the summer of 2018. Then, soil samples were collected at three depths of $0-15 \mathrm{~cm}, 15-45 \mathrm{~cm}$, and $45-100 \mathrm{~cm}$ in each of the six soil profiles per land use category. The control constituted of land under cultivation where none of the CSA practices was implemented. Each of the six control soil profiles per country in Hoima, Nyando, and Lushoto sites was located as adjacent as possible in the same geographic area of the different CSA land use types for representativeness and to ensure similar edaphoclimatic conditions. The land uses with CSA practices since the year 2012 include cropland, agroforestry, grassland, and protected forest land. Cropland practices had crop rotation and intercropping of maize and beans in areas that had soil and water conservation measures. The agroforestry practice had specifically maize and bean crops and various trees like Grevillea robusta, and fruit trees like mangoes. The grassland had natural pasture under improved management that was either grazed upon directly by cattle in Nyando or used for cut and carry zero grazing feeding system in Hoima. The Lushoto farming system did not have cattle, and hence we did not have the grassland land use system for sampling. Accordingly, soil sample collection was done using the synchronic approach. In this approach, soil carbon stock of a given field plot or land use at a given time is compared with a land-use under business as usual/control, representing a reference point (time zero). Undisturbed soil samples were collected from each depth using a core sampler $(2.5 \mathrm{~cm}$ diameter) for bulk density determination. The disturbed samples were also collected from each depth, thoroughly mixed and air-dried. All visible plant materials larger than $2 \mathrm{~mm}$ were removed, and samples were finely grounded and passed through a $2 \mathrm{~mm}$ sieve for determination of soil physicochemical properties.

\subsection{Soil Analysis}

The soil physicochemical analyses were carried out using procedures described by Van Reeuwijk [34]. Briefly, the particle size distribution (sand, silt, and clay) was determined using wet sieving and hydrometer method after removing the soil organic carbon (SOC) by Hydrogen peroxide $\left(\mathrm{H}_{2} \mathrm{O}_{2}\right)$. Bulk density was determined from the core samples viz drying the undisturbed samples at $105^{\circ} \mathrm{C}$ for $24 \mathrm{~h}$. Soil $\mathrm{pH}$ was determined using deionized water at soil to water ratio 
of $1: 2(w / v)$. As the choice of a method to determine Cation exchange capacity (CEC) is highly $\mathrm{pH}$ dependent, the Ammonium acetate $\left(\mathrm{NH}_{4} \mathrm{OAc}\right)$ method was used for the soils [35]. Total carbon was analyzed using the flash combustion method. Then, soil carbon stock was calculated using the formula:

Soil carbon stock $\left(\mathrm{Mg} \mathrm{ha}^{-1}\right)=$ soil carbon $(\%) \times$ bulk density $\left(\mathrm{g} / \mathrm{cm}^{3}\right) \times(1-\mathrm{CF}) \times$ actual depth $(\mathrm{cm})$ where, $\mathrm{CF}$ is the volumetric fraction of coarse fragments $>2 \mathrm{~mm}(\%)$.

Subsequently, the carbon stock of each soil depth was summed up to quantify the total amount of carbon sequestered up to $100 \mathrm{~cm}$ depth. The conversion of total carbon stock to carbon equivalent $\left(\mathrm{CO}_{2} \mathrm{eq} / \mathrm{ha}\right)$ was made with the assumption that one ton of carbon equals to 3.67 tons of $\mathrm{CO}_{2}$.

\subsection{Statistical Analyses}

To determine climate change mitigation potential of improved land uses, linear mixed model was used. Replication was considered a random effect whereas improved land uses and control were fixed effect variables. All ANOVA assumptions were checked prior to data analysis. Shapiro and Levene tests were used to check the assumptions of normality and homogeneity of variance, respectively. Cook distance was used to check the outliers. The 5th and 95th percentiles were used to replace the outliers. If significant differences were found between the improved land uses, Tukey's range test $(p<0.05)$ was used for mean separations. All statistical analyses were performed using the R software version 3.6.0 and Genstat analysis Software (2015).

\section{Results and Discussion}

A portfolio of CSA practices has been implemented in East African countries since 2012 [3]. The effect of integrated implementation of these CSA practices on soil carbon sequestration is shown in Figures 2 and 3. The results reveal that restoration of degraded lands through CSA practices stored 1.3-2.1 times more soil carbon than the control at one-meter soil depth. Similarly, CSVs sequestered 1.4-3 times more soil carbon than the control at the surface soil $(0-15 \mathrm{~cm})$ and subsequently the emissions under CSVs was reduced by $95-158,42-127$, and $86-124 \mathrm{Mg} \mathrm{CO}_{2}$ eq ha $^{-1}$ in Uganda (Hoima), Kenya (Nyando) and Tanzania (Lushoto) sites, respectively. The effectiveness of CSA practices on soil carbon sequestration was more pronounced at the soil surface. However, in the Ugandan site, the improved land uses stored more soil carbon $(p<0.05)$ than control throughout the soil profile (Figure 2a). Our findings also demonstrated marginal differences in SOC levels between the improved land uses (Figures 2 and 3). In the Ugandan and Kenyan sites, improved forestlands contained almost twice more soil carbon than other improved land uses. Similarly, the forestlands and agroforestry contained 1.2 times more soil carbon than improved croplands at the Tanzanian site. In the following sections, there is a detailed discussion on how climate change mitigation potential of soils improved through the portfolio of CSA practices.

\subsection{Cropland}

The combination of CSA interventions that has been practiced within the croplands include: (i) terraces coupled with Napier grass (Pennisetum purpureum); (ii) grass strips; (iii) cereal-legumes rotation; (iv) minimum tillage; and (v) farm yard manure (FYM) application. As a result, improved croplands sequestered $95 \%, 117 \%$ and $136 \%$ more soil carbon than the control in the Uganda, Kenya and Tanzania sites respectively. Similarly, Hu et al. [36] found a 90\% increase in soil carbon content in croplands due to long-term application of compost and FYM. The effect of CSA practices was more pronounced at the surface soil, which is expected because many of these practices were implemented on the surface soil to manage soil fertility. 

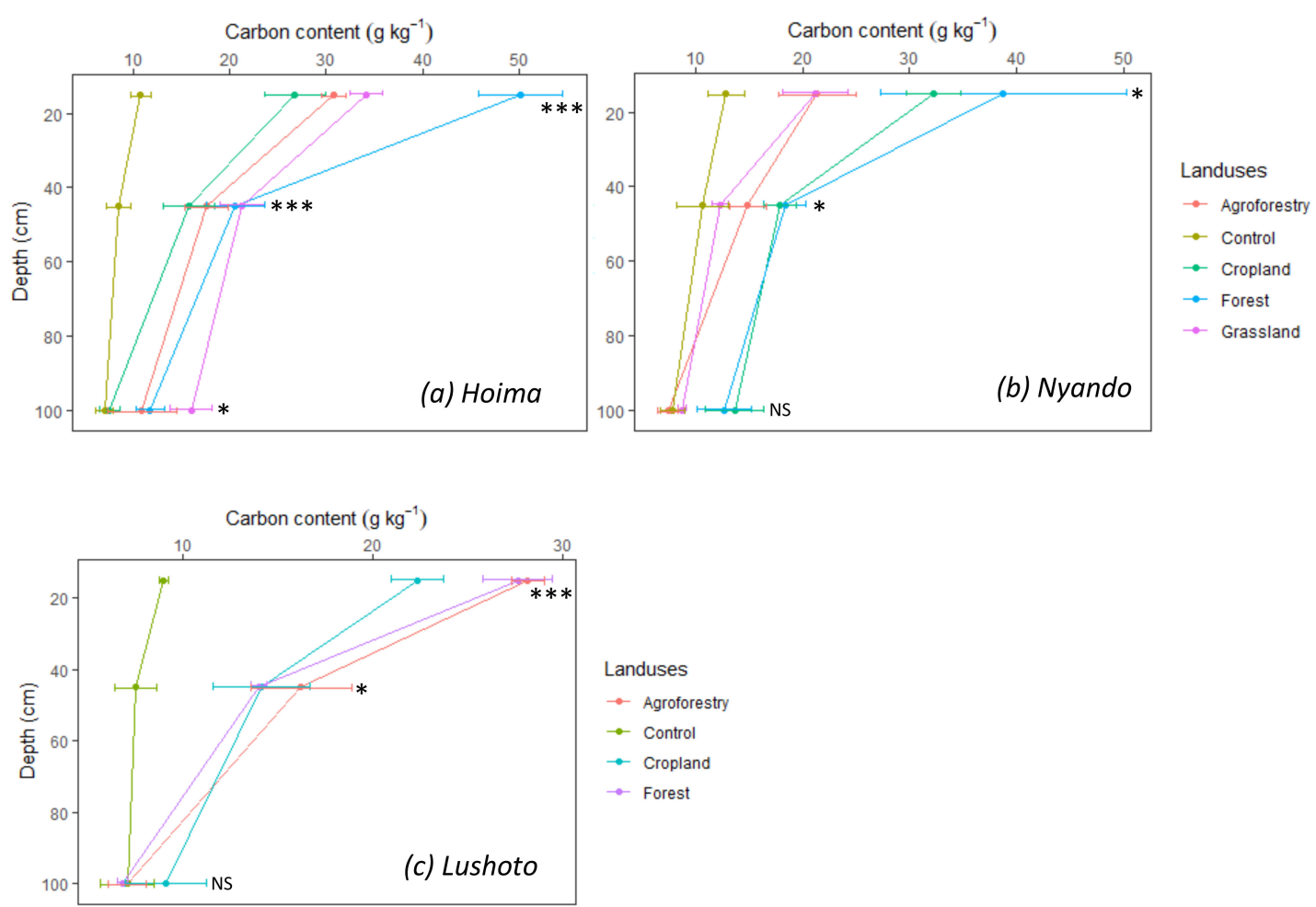

Figure 2. Soil organic carbon content in the deep soil profile $(0-100 \mathrm{~cm})$. Cropland, agroforestry, grassland, forest, and control land uses. Error bars show standard error of the mean. NS: non-significant, $* * *, * *$, and * indicate significant differences at $p \leq 0.001, p \leq 0.01$, and $p \leq 0.05$, respectively.
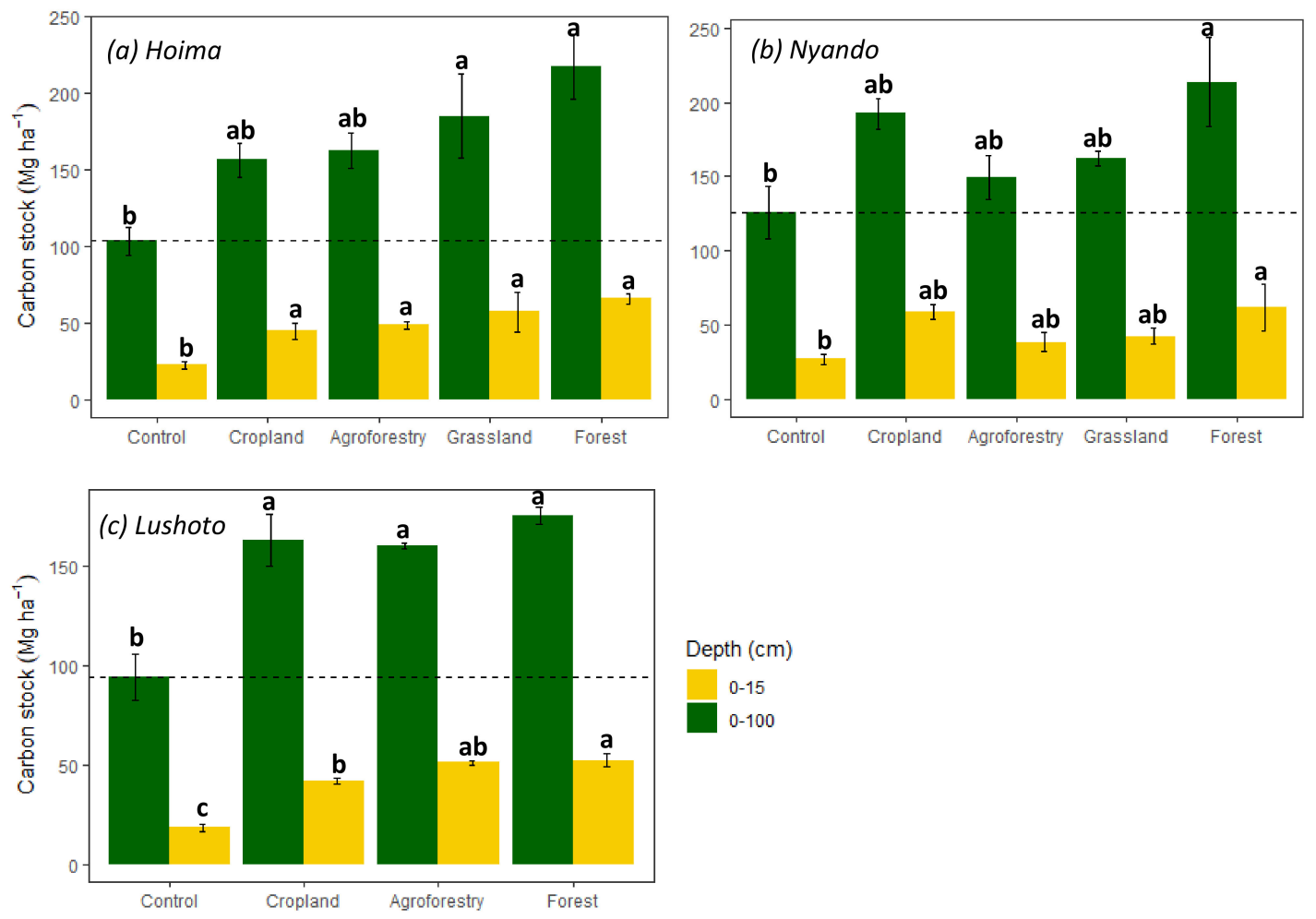

Figure 3. Total organic carbon stocks of the surface soil $(0-15 \mathrm{~cm})$ (yellow) and throughout the soil profile $(0-100 \mathrm{~cm})$ (green). Cropland, agroforestry, grassland, forest, and control land uses. Error bars show standard error of the mean. Different letters across the sampling depths indicate significant differences between the means of carbon stock at $p<0.05$. 
The annual increase in soil carbon stocks of the surface soil is estimated to be between 1.6 and 6.2 $\mathrm{MgC} \mathrm{ha}^{-1} \mathrm{yr}^{-1}$, which is higher than the rate reported earlier in Sub-Sharan African cropping systems [24,37]. For example, Powlson et al. [24] found annual soil carbon increase between 0.28 to $0.96 \mathrm{MgC} \mathrm{ha}^{-1} \mathrm{yr}^{-1}$ due to conservation agriculture, whereas Zomer et al. [37] predicted annual carbon increase of $1.1 \mathrm{MgC} \mathrm{ha}^{-1} \mathrm{yr}^{-1}$ in many East African cropping systems. In the present study, the high annual soil carbon sequestration rate is likely to be attributed to a portfolio of CSA practices. As compared to the control, cropland restoration through a portfolio of CSA practices reduced emissions by 86,80 and $115 \mathrm{Mg} \mathrm{CO}_{2}$ eq ha $^{-1}$ in the Tanzania, Uganda and Kenya sites respectively. The findings imply that cropland management should be based on integration of several CSA practices rather than a one-practice approach to mitigate climate change through soil carbon sequestration. Most of the CSA interventions alter the plowing depth through continuous application of plant residues and animal manure. Thus, $25-30 \%$ of carbon was observed at the surface soil $(0-15 \mathrm{~cm})$ and the impact of CSA practices tended to decrease with soil depth.

\subsection{Grassland}

The potential of improved grasslands to sequester carbon compared to the control was studied in the Ugandan and Kenyan sites because it did not exist in the Tanzanian site. Rotational grazing was practiced in Kenya, whereas the cut-and-carry system was practiced in Uganda. At a one-meter depth, the Uganda cut-and-carry grassland management sites stored $80 \%$ more soil carbon $(p<0.05)$ than the control. Similarly, grassland sites under rotational grazing management in Kenya sequestered $28 \%$ more soil carbon than the control, but the effect was marginal (Figure 3). Even though grassland ecosystems contain substantial amounts of soil organic carbon, the soil carbon stocks are sensitive to management [38]. The substantial difference between the two grassland systems in terms of soil carbon stocks also demonstrate the importance of grassland management to mitigate climate change through carbon sequestration. In agreement with our findings, Sanderman et al. [25] found a marginal effect of rotational grazing on soil carbon sequestration after 15 years of implementation. The increase in annual carbon stocks due to improved grassland was $2.2 \mathrm{MgC} \mathrm{ha}^{-1} \mathrm{yr}^{-1}$ under rotational grazing grassland system and $4.9 \mathrm{Mg} \mathrm{C} \mathrm{ha}^{-1} \mathrm{yr}^{-1}$ under cut-and-carry system, which is comparable to Conant et al. [38] who reported carbon sequestration between 0.1 and $3 \mathrm{MgC} \mathrm{ha}^{-1} \mathrm{yr}^{-1}$ under different improved grasslands. At the global level, Deng et al. [12] reported soil carbon stock change at the rate of $0.3 \mathrm{MgC} \mathrm{ha}^{-1} \mathrm{yr}^{-1}$ in grasslands. The unusually high carbon sequestration rate in this study is likely to be due to the improved grazing system. As compared to the control, emissions from grasslands were reduced by 126 and $57 \mathrm{Mg} \mathrm{CO}_{2}$ eq ha $^{-1}$ due to the cut-and-carry and rotational grazing systems respectively.

\subsection{Agroforestry}

Improved agroforestry practices included several multipurpose leguminous trees and shrubs, such as Acacia anguistissima, Cajanus cajan, Gliricidia sepium, Leucaena collinsii, Sesbania sesban, Tephrosia candida and Tephrosia vogelii. In addition, Grevillea robusta and different fruit trees, mostly Mangifera indica were planted. Accordingly, land management through agroforestry practices stored $42 \%, 119 \%$, and $185 \%$ more soil carbon in the Kenya, Uganda and Tanzania sites respectively compared to the control. Implementation of agroforestry practices reduced emissions by 42,95 , and $119 \mathrm{Mg} \mathrm{CO}_{2}$ eq ha ${ }^{-1}$ in these sites in Kenya, Uganda and Tanzania respectively. The annual increase in soil carbon stocks due to agroforestry practices ranged between $1.6 \mathrm{MgC} \mathrm{ha}^{-1} \mathrm{yr}^{-1}$ and $4.7 \mathrm{MgC} \mathrm{ha}^{-1} \mathrm{yr}^{-1}$. Agroforestry practices improved climate change mitigation potential of carbon poor degraded soils through several mechanisms. For instance, intensive management practices, such as litter incorporation and manure application coupled with soil conservation measures, likely contributed to the higher soil carbon sequestration in the agroforestry systems. Carbon losses that normally occur through soil disturbance [39] was controlled by minimum tillage practices in the agroforestry systems. The root system of multipurpose leguminous trees and shrubs are also responsible for carbon 
input [40], carbon stabilization within soil aggregates [41-43], and reduced erosion [44]. De Stefano and Jacobson [45] performed a meta-analysis on soil carbon sequestration potential of agroforestry and found up to a $40 \%$ increase in SOC stocks due to the transition from cropland to agroforestry-which is in accordance with the present study.

\subsection{Forest Land}

The forest land had been protected from both livestock and human disturbance. At one-meter depth, forest land sequestered $70 \%, 110 \%$ and $86 \%$ more carbon than the control in the Kenya, Uganda and Tanzania sites respectively. Similarly, the surface soil under forest stored almost twice more carbon than the control, irrespective of location. Restoration of highly degraded tropical soils through forest establishment reduced emissions by 127, 158, and $124 \mathrm{Mg} \mathrm{CO}_{2} \mathrm{eq} \mathrm{ha}^{-1}$ in the Kenya, Uganda, and Tanzania sites respectively. Protected forests increased soil carbon stocks at the rate of 5-6 Mg C ha ${ }^{-1} \mathrm{yr}^{-1}$, confirming that forests are more efficient in enhancing the climate change mitigation capability of degraded soils in the short term ( $<10$ years), as compared to other improved land uses (i.e. cropland, grassland and/or agroforestry). Similarly, Shi et al. [40] revealed soil organic carbon accumulation rates of $2 \mathrm{MgC} \mathrm{ha}^{-1} \mathrm{yr}^{-1}$ due to conversion of non-forest lands to forest. In the present study, the forest land was protected from human disturbance; hence, the highest soil carbon sequestration rate is expected. The contribution of sub-surface soils towards climate change mitigation through soil carbon sequestration has not been widely studied. In the present study, about $70-75 \%$ of the soil carbon stocks was found below $15 \mathrm{~cm}$ depth, irrespective of type of land use and/or locations. Similarly, a significant amount of soil carbon in the subsoils was reported previously in forest land [46] and grasslands [47-49]. These findings suggest that sub-surface soils should be considered while assessing the carbon sequestration potential of CSA practices. The bulk density in the $0-15 \mathrm{~cm}$ topsoil for forest land was lower compared to the control (Figure 4) in the three sites, that is attributed to the higher levels of organic matter. The soil compaction especially in the control contributed to the high bulk density levels.
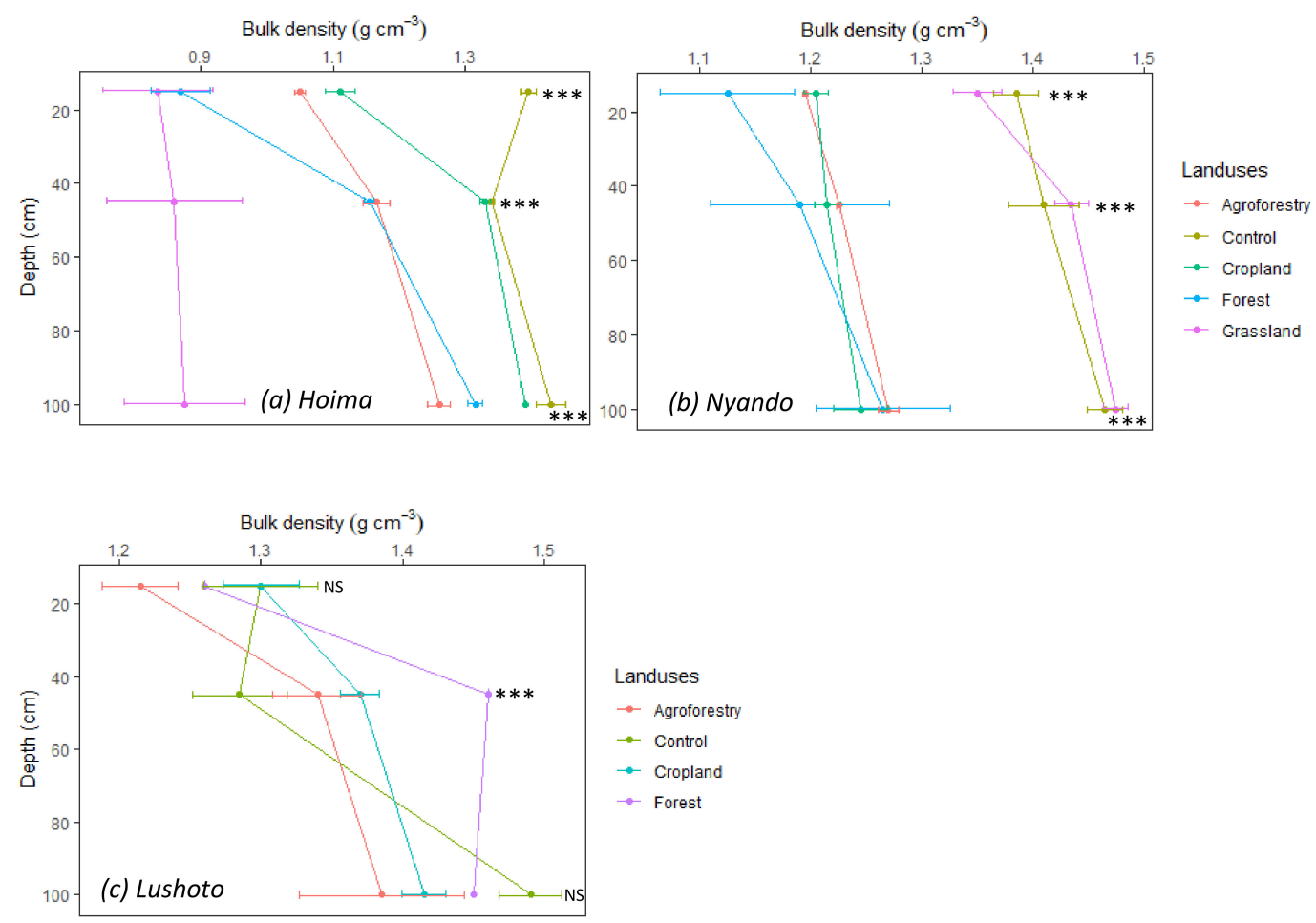

Figure 4. Bulk density at different soil depths $(0-100 \mathrm{~cm})$. Cropland, agroforestry, grassland, forest, and control land uses. Error bars show standard error of the mean. NS: non-significant, ${ }^{* * *},{ }^{* *}$, and * indicate significant differences at $p \leq 0.001, p \leq 0.01$, and $p \leq 0.05$, respectively. 


\section{Conclusions}

This study provides evidence that land restoration through a portfolio of CSA practices has the potential to enhance climate change mitigation of highly degraded tropical soils. The annual increase in soil carbon sequestration due to CSA practices ranged between 1.63 and $6.2 \mathrm{Mg} \mathrm{C} \mathrm{ha}^{-1} \mathrm{yr}^{-1}$ and varied between the improved land uses across different geographic locations. Generally, in the seven-year timeframe, improved forestland had the highest potential for soil carbon sequestration (5-6 Mg C ha ${ }^{-1} \mathrm{yr}^{-1}$ ), followed by improved grasslands and croplands. The soil carbon sequestration potential was $2.2 \mathrm{MgC} \mathrm{ha}^{-1} \mathrm{yr}^{-1}$ under rotational grazing system and $4.9 \mathrm{MgC} \mathrm{ha}^{-1} \mathrm{yr}^{-1}$ under cut-and-carry system, indicating the possibility of grassland management for climate change mitigation. The portfolio of CSA practices accounted for the reduction of emissions by $87-420 \mathrm{Mg} \mathrm{CO}_{2}$ eq ha ${ }^{-1}$. The findings therefore demonstrate the positive role that CSA practices bring into the landscape for climate change mitigation. In addition, this study can inform policy making processes in the design of agricultural programs which have mitigation co-benefits. This study was limited to three East African countries. Further studies are therefore required in other countries to draw a general conclusion on the climate change mitigation potential of CSA practices through the CSVs approach.

Author Contributions: G.A.: Conceptualization, soil sampling, statistical analysis, and writing—original draft preparation. J.W.R. Conceptualization, investigation, soil sampling, laboratory analysis supervision, statistical analysis support, writing - review and editing. A.N. Statistical analysis, writing-review and editing. D.S. Funding acquisition, conceptualization, investigation, writing-review and editing. M.R.: Conceptualization, investigation, writing-review and editing. All authors have read and agreed to the published version of the manuscript.

Funding: This research was financially supported through CCAFS-EC grant reference: 2000002575 for the project on Building Livelihoods and Resilience to Climate Change in East and West Africa: Agricultural Research for Development (AR4D) for large-scale implementation of Climate-Smart Agriculture. The funds are administered by the International Fund for Agricultural Development (IFAD), Rome Italy while the project is implemented by Alliance Bioversity-CIAT.

Acknowledgments: The Kenya Agricultural and Livestock Research Organization (KALRO) and Vi Agroforestry are acknowledged for providing support during fieldwork in Nyando CSVs. Maseno University is acknowledged for bulk density determination of Nyando CSVs soil samples. The Tanzania Agricultural Research Institute (TARI) is acknowledged for providing support during fieldwork as well as for bulk density determination of the Lushoto CSVs soil samples. The Uganda National Agricultural Research Organisation (NARO) is acknowledged for providing support during fieldwork as well as for bulk density determination of the Hoima CSVs soil samples.

Conflicts of Interest: The authors declare no conflict of interest.

\section{References}

1. Lesk, C.; Rowhani, P.; Ramankutty, N. Influence of extreme weather disasters on global crop production. Nat. Cell Biol. 2016, 529, 84-87. [CrossRef] [PubMed]

2. Trenberth, K.E.; Dai, A.; Van Der Schrier, G.; Jones, P.D.; Barichivich, J.; Briffa, K.R.; Sheffield, J. Global warming and changes in drought. Nat. Clim. Chang. 2013, 4, 17-22. [CrossRef]

3. Recha, J.; Kimeli, P.; Atakos, V.; Radeny, M.; Mungai, C. Stories of Success: Climate-Smart Villages in East Africa; CGIAR Research Program on Climate Change, Agriculture and Food Security (CCAFS): Wageningen, The Netherlands, 2017. Available online: https://hdl.handle.net/10568/81030 (accessed on 6 October 2020).

4. Reynolds, T.W.; Waddington, S.R.; Anderson, C.L.; Chew, A.; True, Z.; Cullen, A. Environmental impacts and constraints associated with the production of major food crops in Sub-Saharan Africa and South Asia. Food Secur. 2015, 7, 795-822. [CrossRef]

5. FAO; OECD. Food Security and Nutrition: Challenges for Agriculture and the Hidden Potential of Soil; A Report to the G20 Agriculture Deputies; FAO: Rome, Italy, 2018.

6. Oertel, C.; Matschullat, J.; Zurba, K.; Zimmermann, F.; Erasmi, S. Greenhouse gas emissions from soils-A review. Geochemistry 2016, 76, 327-352. [CrossRef]

7. Cloy, J.; Smith, K. Greenhouse Gas Sources and Sinks. Encycl. Anthr. 2018, 2, 391-400. [CrossRef]

8. Lehmann, J.; Kleber, M. The contentious nature of soil organic matter. Nat. Cell Biol. 2015, 528, 60-68. [CrossRef] 
9. Schmidt, M.W.; Torn, M.S.; Abiven, S.; Dittmar, T.; Guggenberger, G.; Janssens, I.A.; Kleber, M.; Kögel-Knabner, I.; Lehmann, J.; Manning, D.A.C.; et al. Persistence of soil organic matter as an ecosystem property. Nat. Cell Biol. 2011, 478, 49-56. [CrossRef]

10. Scharlemann, J.P.; Tanner, E.V.; Hiederer, R.; Kapos, V. Global soil carbon: Understanding and managing the largest terrestrial carbon pool. Carbon Manag. 2014, 5, 81-91. [CrossRef]

11. Gougoulias, C.; Clark, J.M.; Shaw, L.J. The role of soil microbes in the global carbon cycle: Tracking the below-ground microbial processing of plant-derived carbon for manipulating carbon dynamics in agricultural systems. J. Sci. Food Agric. 2014, 94, 2362-2371. [CrossRef]

12. Deng, L.; Zhu, G.-Y.; Tang, Z.-S.; Shangguan, Z. Global patterns of the effects of land-use changes on soil carbon stocks. Glob. Ecol. Conserv. 2016, 5, 127-138. [CrossRef]

13. Deng, L.; Sweeney, S.; Shangguan, Z.-P. Long-Term Effects of Natural Enclosure: Carbon Stocks, Sequestration Rates and Potential for Grassland Ecosystems in the Loess Plateau. CLEAN Soil Air Water 2013, 42, 617-625. [CrossRef]

14. Bell, S.M.; Barriocanal, C.; Terrer, C.; Rosell-Melé, A. Management opportunities for soil carbon sequestration following agricultural land abandonment. Environ. Sci. Policy 2020, 108, 104-111. [CrossRef]

15. Winowiecki, L.A.; Vågen, T.-G.; Massawe, B.; Jelinski, N.A.; Lyamchai, C.; Sayula, G.; Msoka, E. Landscape-scale variability of soil health indicators: Effects of cultivation on soil organic carbon in the Usambara Mountains of Tanzania. Nutr. Cycl. Agroecosyst. 2015, 105, 263-274. [CrossRef]

16. Doggart, N.; Morgan-Brown, T.; Lyimo, E.; Mbilinyi, B.; Meshack, C.K.; Sallu, S.M.; Spracklen, D.V. Agriculture is the main driver of deforestation in Tanzania. Environ. Res. Lett. 2020, 15, 034028. [CrossRef]

17. Kassa, H.; Dondeyne, S.; Poesen, J.; Frankl, A.; Nyssen, J. Transition from Forest-based to Cereal-based Agricultural Systems: A Review of the Drivers of Land use Change and Degradation in Southwest Ethiopia. Land Degrad. Dev. 2016, 28, 431-449. [CrossRef]

18. Yang, Y.; Tilman, D.; Furey, G.; Lehman, C. Soil carbon sequestration accelerated by restoration of grassland biodiversity. Nat. Commun. 2019, 10, 1-7. [CrossRef] [PubMed]

19. Lipper, L.; Thornton, P.; Campbell, B.M.; Baedeker, T.; Braimoh, A.; Bwalya, M.; Caron, P.; Cattaneo, A.; Garrity, D.P.; Henry, K.; et al. Climate-smart agriculture for food security. Nat. Clim. Chang. 2014, 4, 1068-1072. [CrossRef]

20. Faurès, J.; Bartley, D.; Bazza, M.; Burke, J.; Hoogeveen, J.; Soto, D.; Steduto, P. Climate Smart Agriculture Sourcebook; FAO: Rome, Italy, 2013; p. 557. Available online: http://www.fao.org/3/a-i3325e.pdf (accessed on 6 October 2020).

21. Ran, L.; Lu, X.; Fang, N.; Yang, X. Effective soil erosion control represents a significant net carbon sequestration. Sci. Rep. 2018, 8, 12018. [CrossRef]

22. Land, M.; Haddaway, N.R.; Hedlund, K.; Jørgensen, H.B.; Kätterer, T.; Isberg, P.-E. How do selected crop rotations affect soil organic carbon in boreo-temperate systems? A systematic review protocol. Environ. Evid. 2017, 6, 708. [CrossRef]

23. Feyisa, K.; Beyene, S.; Angassa, A.; Said, M.Y.; De Leeuw, J.; Abebe, A.; Megersa, B. Effects of enclosure management on carbon sequestration, soil properties and vegetation attributes in East African rangelands. Catena 2017, 159, 9-19. [CrossRef]

24. Powlson, D.; Stirling, C.M.; Thierfelder, C.; White, R.P.; Jat, M. Does conservation agriculture deliver climate change mitigation through soil carbon sequestration in tropical agro-ecosystems? Agric. Ecosyst. Environ. 2016, 220, 164-174. [CrossRef]

25. Sanderman, J.; Reseigh, J.; Wurst, M.; Young, M.-A.; Austin, J. Impacts of Rotational Grazing on Soil Carbon in Native Grass-Based Pastures in Southern Australia. PLoS ONE 2015, 10, e0136157. [CrossRef] [PubMed]

26. Aggarwal, P.; Jarvis, A.; Campbell, B.; Zougmoré, R.B.; Khatri-Chhetri, A.; Vermeulen, S.J.; Loboguerrero, A.M.; Sebastian, L.S.; Kinyangi, J.; Bonilla-Findji, O.; et al. The climate-smart village approach: Framework of an integrative strategy for scaling up adaptation options in agriculture. Ecol. Soc. 2018, 23. [CrossRef]

27. Ogada, M.; Rao, E.J.; Radeny, M.; Recha, J.; Solomon, D. Climate-smart agriculture, household income and asset accumulation among smallholder farmers in the Nyando basin of Kenya. World Dev. Perspect. 2020, 18, 100203. [CrossRef] 
28. Massawe, H.J.B. Landform and Soil Analysis for Predicting Distribution of Plague Reservoirs and Vectors in Mavumo Area, Lushoto District, Tanzania. Ph.D. Thesis, Sokoine University of Agriculture, Morogoro, Tanzania, 2011. Available online: https://www.semanticscholar.org/paper/Landform-and-soil-analysis-forpredicting-of-plague-Massawe/ea6bfde77b3e215938bd710448d4372078da43ec (accessed on 1 September 2020).

29. Ndakidemi, P.; Semoka, J. Soil Fertility Survey in Western Usambara Mountains, Northern Tanzania. Pedosphere 2006, 16, 237-244. [CrossRef]

30. Gathenya, M.; Mwangi, H.; Coe, R.; Sang, J.K. Climate- and Land Use-Induces Risks To Watershed Services in the Nyando River Basin, Kenya. Exp. Agric. 2011, 47, 339-356. [CrossRef]

31. Sijmons, K.; Kiplimo, J.; Förch, W.; Thornton, P.K.; Radeny, M.; Kinyangi, J. CCAFS Site Atlas-Nyando/Katuk Odeyo; CCAFS Site Atlas Series; The CGIAR Research Program on Climate Change, Agriculture and Food Security (CCAFS): Copenhagen, Denmark, 2013. Available online: www.ccafs.cgiar.org (accessed on 1 September 2020).

32. FAO. World Reference Base for Soil Resources 2006; World Soil Resources Reports No. 103; Food and Agriculture Organization of the United Nations: Rome, Italy, 2006. Available online: http://www.fao.org/3/a-a0510e.pdf (accessed on 1 September 2020).

33. Sijmons, K.; Kiplimo, J.; Förch, W.; Thornton, P.K.; Radeny, M.; Kinyangi, J. CCAFS Site Atlas-Albertine Rift/Hoima; CCAFS Site Atlas Series; The CGIAR Research Program on Climate Change, Agriculture and Food Security (CCAFS): Copenhagen, Denmark, 2013. Available online: www.ccafs.cgiar.org (accessed on 1 September 2020).

34. Van Reeuwijk, L.P. Procedures for Soil Analysis, 3rd ed.; International Soil Reference and Information Center (ISRIC): Wageningen, The Netherlands, 1992. Available online: https://www.scirp.org/(S(i43dyn45teexjx455qlt3d2q) (accessed on 6 October 2020).

35. Hendershot, W.; Lalande, H.; Duquette, M. Soil Reaction and Exchangeable Acidity. In Soil Sampling and Methods of Analysis, 2nd ed.; CRC Press: Boca Raton, FL, USA. [CrossRef]

36. Hu, C.; Xia, X.; Chen, Y.; Han, X. Soil carbon and nitrogen sequestration and crop growth as influenced by long-term application of effective microorganism compost. Chil. J. Agric. Res. 2018, 78, 13-22. [CrossRef]

37. Zomer, R.J.; Bossio, D.A.; Sommer, R.; Verchot, L.V. Global Sequestration Potential of Increased Organic Carbon in Cropland Soils. Sci. Rep. 2017, 7, 15554. [CrossRef]

38. Conant, R.T.; Cerri, C.E.P.; Osborne, B.B.; Paustian, K. Grassland management impacts on soil carbon stocks: A new synthesis. Ecol. Appl. 2017, 27, 662-668. [CrossRef]

39. Nair, V.D.; Graetz, D. Agroforestry as an approach to minimizing nutrient loss from heavily fertilized soils: The Florida experience. Agrofor. Syst. 2004, 61, 269-279. [CrossRef]

40. Shi, L.; Feng, W.; Xu, J.; Kuzyakov, Y. Agroforestry systems: Meta-analysis of soil carbon stocks, sequestration processes, and future potentials. Land Degrad. Dev. 2018, 1-12. [CrossRef]

41. Cardinael, R.; Mao, Z.; Prieto, I.; Stokes, A.; Dupraz, C.; Kim, J.H.; Jourdan, C. Competition with winter crops induces deeper rooting of walnut trees in a Mediterranean alley cropping agroforestry system. Plant Soil 2015, 391, 219-235. [CrossRef]

42. Le Bissonnais, Y.; Prieto, I.; Roumet, C.; Nespoulous, J.; Metayer, J.; Huon, S.; Villatoro, M.; Stokes, A. Soil aggregate stability in Mediterranean and tropical agro-ecosystems: Effect of plant roots and soil characteristics. Plant Soil 2017, 424, 303-317. [CrossRef]

43. Upson, M.A.; Burgess, P.J. Soil organic carbon and root distribution in a temperate arable agroforestry system. Plant Soil 2013, 373, 43-58. [CrossRef]

44. Béliveau, A.; Lucotte, M.; Davidson, R.; Paquet, S.; Mertens, F.; Passos, C.J.; Romana, C.A. Reduction of soil erosion and mercury losses in agroforestry systems compared to forests and cultivated fields in the Brazilian Amazon. J. Environ. Manag. 2017, 203, 522-532. [CrossRef]

45. De Stefano, A.; Jacobson, M.G. Soil carbon sequestration in agroforestry systems: A meta-analysis. Agrofor. Syst. 2017, 92, 285-299. [CrossRef]

46. Lorenz, K.; Lal, R.; Preston, C.M.; Nierop, K. Strengthening the soil organic carbon pool by increasing contributions from recalcitrant aliphatic bio(macro)molecules. Geoderma 2007, 142, 1-10. [CrossRef]

47. Kempen, B.; Dalsgaard, S.; Kaaya, A.K.; Chamuya, N.; Ruipérez-González, M.; Pekkarinen, A.; Walsh, M.G. Mapping topsoil organic carbon concentrations and stocks for Tanzania. Geoderma 2019, 337, 164-180. [CrossRef] 
48. Torres-Sallan, G.; Creamer, R.; Lanigan, G.J.; Reidy, B.; Byrne, K.A. Effects of soil type and depth on carbon distribution within soil macroaggregates from temperate grassland systems. Geoderma 2018, 313, 52-56. [CrossRef]

49. Ward, S.E.; Smart, S.M.; Quirk, H.; Tallowin, J.R.B.; Mortimer, S.R.; Shiel, R.S.; Wilby, A.; Bardgett, R.D. Legacy effects of grassland management on soil carbon to depth. Glob. Chang. Biol. 2016, 22, 2929-2938. [CrossRef]

(C) 2020 by the authors. Licensee MDPI, Basel, Switzerland. This article is an open access article distributed under the terms and conditions of the Creative Commons Attribution (CC BY) license (http://creativecommons.org/licenses/by/4.0/). 